\title{
Recent trends in photoelectrochemical cells
}

\author{
G V SUBBA RAO \\ Materials Science Research Centre. Indian Institute of Technology, Madras 600 036, India \\ Abstract. A hrief survey is presented of the recent developments and emerging trends in \\ research in photoelectrochemical cell for solar energy conversion utilizing semiconductor \\ electrodes.
}

Keywords. Photoelectrochemical cell; semiconductor electrodes.

\section{Introduction}

Solar energy as received on the earth's surface constitutes less than $3 \%$ ultraviolet, about $44 \%$ visible region, about $52 \%$ near infrared and the rest in the far-infrared regions. Sunlight can be usefully harnessed in several ways. Semiconductor (SC)based photoelectrochemical (PEC) cell forms one of the chemical routes for trapping solar energy (ChemTrapse). PEC cells can be classified into two types. When sunlight energy is converted into electrical energy, the device is called liquid junction solar cells (LJSC). In the second type, light energy is converted into chemical energy in the form of fuels and is known as photo-electrosynthesis (PES) cells. An example of the latter is the production of hydrogen by the photo-assisted electrolysis (PAE) of water. In PEC cells, the junction formation is easier (mere dipping of the semiconductor in the electrolyte) compared to the $\mathrm{p}-\mathrm{n}$ junction formation in solid state photovoltaic cells (e.g. silicon). Energy conversion efficiencies $(\eta)$ as high as $13 \%$ have been realized in PAE cells and $\sim 20 \%$ in PEC cells. A large number of semiconductors of the mixed oxide and chalcogenide types have been studied for their PEC performance. However, practical solar cells based on these PEC and PAE cells have not been made so far because of the stringent materials requirement. Longterm stability of these SC electrodes under irradiation in the presence of aqueous electrolytes is a lingering problem. There is therefore a need to look for new materials as well as improve the characteristics of known SC materials for use in PEC and PAE cells. Several reviews have appeared in the literature about the stateof-the art of PEC cells (Kalyanasundaram 1985; Rajeshwar 1985; Wrighton 1985; Tributsch 1986).

\section{PEC, PAE and PES cells}

A PEC cell consists of a photoresponsive n-type SC electrode and a counterelectrode dipped in a suitable electrolyte (aqueous or nonaqueous). The counterelectrode can also be a photoresponsive p-type SC electrode. When the $\mathrm{SC} /$ electrolyte junction is illuminated by light of energy $h v \geqslant E_{g}$, the band gap of the SC electrode, photons are absorbed by the SC electrode producing electron-hole pairs. The electrons are excited into the conduction band (CB), while holes will be left behind in the valence band (VB) of the semiconductor. Because of the potential barrier (space-charge region) created in the $\mathrm{SC}$ after the $\mathrm{SC} /$ electrolyte junction formation, electrons and 
holes are separated and their recombination inhibited. The majority carriers (electrons in the case of n-type SC electrode) flow to the counterelectrode while the minority carriers (holes in the case of n-type electrode) reach the surface and effect an electrochemical reaction (oxidation at the n-type SC electrode and reduction at the counterelectrode).

In an LJSC, a redox electrolyte system (e.g. polysulphide or iodine/iodide (aq.)) is employed where the oxidation reaction at the anode is counterbalanced by the reduction reaction at the cathode and hence there is no net change in the chemical composition of the redox electrolyte $(\Delta G=0)$ and light is converted to dc-electricity. In PAE and PES cells, the electrochemical reactions lead to stable and recoverable products $(\Delta G \neq 0)$. High efficiency LJSC's and PAE cells that have been established over the years are listed in tables 1 and 2 . The maximum theoretical values of $\eta$ obtainable for LJSC's are 25-30\% and 20-30\% for PAE cells (Memming 1980). For oxidic materials in PAE cells, $\eta_{\text {theor. }}$ is $\sim 7 \%$ when $E_{g} \geqslant 3.0 \mathrm{eV}$ (Weber and Dignam 1986).

Table 1. High conversion efficiency liquid junction solar cells.

\begin{tabular}{|c|c|c|c|c|}
\hline $\begin{array}{l}\text { Electrode } \\
\left(E_{g}, \mathrm{eV}\right)\end{array}$ & $\begin{array}{l}\text { Electrolyte } \\
\quad \text { (aq.) }\end{array}$ & $\begin{array}{l}\text { Efficiency } \\
\qquad \eta^{*}\end{array}$ & Remarks & Reference \\
\hline $\begin{array}{l}n-\mathrm{CdSe}_{0.65} \mathrm{Te}_{0.35} \\
(1.47)\end{array}$ & $\mathrm{CsS}_{x}+0.5 \mathrm{mMCuSO}_{4}$ & $12.7 \%$ & Single crystal electrode & $\begin{array}{l}\text { Levy-Clement } \\
\text { et al }(1985)\end{array}$ \\
\hline$n-\mathrm{CdSe}(1 \cdot 7)$ & Ferri/ferro cyanide & $12 \cdot 4 \%$ & Single crystal electrode & Frese Jr (1982) \\
\hline$n-\mathrm{CuInSe}_{2}(1.01)$ & $\begin{array}{l}2 \mathrm{MHI}+2 \mathrm{MK} \mathrm{I}+ \\
0.02 \mathrm{M} \mathrm{In} 2+0.02 \mathrm{MCu} \mathrm{I} \\
+0.02 \mathrm{M} \mathrm{In}_{2}\left(\mathrm{SO}_{4}\right)_{3}\end{array}$ & $12.0 \%$ & $\begin{array}{l}\text { Surface modified with } \\
\operatorname{In}_{2} \mathrm{O}_{3} \text { layer }\end{array}$ & $\begin{array}{l}\text { Cahen and Chen } \\
\text { (1984); Menezes } \\
\text { (1984) }\end{array}$ \\
\hline$p-\operatorname{InP}(1 \cdot 35)$ & $\mathrm{VCl}_{3}-\mathrm{VCl}_{2}-\mathrm{HCl}$ & $13.0 \%$ & $\begin{array}{l}\text { Surface modified with } \\
\mathrm{In}_{2} \mathrm{O}_{3} \text { layer }\end{array}$ & Heller et al (1981) \\
\hline$n-W_{S e}(1 \cdot 35)$ & $2 \mathrm{MK} \mathrm{I}+0.02 \mathrm{MI}_{2}$ & $19.8 \%$ & $\begin{array}{l}\mathrm{SeCl}_{4} \text {-used as the transport- } \\
\text { ing agent }\end{array}$ & $\begin{array}{l}\text { Azaiez et al } \\
(1986)\end{array}$ \\
\hline$n$-GaAs $(1 \cdot 42)$ & $\begin{array}{l}\text { Ferrocene-ferrocenium } \\
\text { in } \mathrm{LiClO}_{4} \text { methanol } \\
\text { solution }\end{array}$ & $15.5 \%$ & $\begin{array}{l}\text { Similar to high efficiency } \\
\text { solar cell ( } \mathrm{Si} / \text { methanol) }\end{array}$ & $\begin{array}{l}\text { Gabouze and } \\
\text { Gorochov (1986) }\end{array}$ \\
\hline
\end{tabular}

$\overline{\left.\eta^{*}=\left\{(\mathrm{I} \times \mathrm{V})_{\max } / \text { /optical power input }\right)\right\} \times 100 \text {; where }(\mathrm{I} \times \mathrm{V})_{\max } \text { is the maximum output power of the cell. }}$

Table 2. Photoassisted electrolysis cells.

\begin{tabular}{|c|c|c|c|c|}
\hline \multirow[b]{2}{*}{ Electrodes } & \multicolumn{3}{|c|}{ Efficiency } & \multirow[b]{2}{*}{ Reference } \\
\hline & Electrolyte & $\eta^{*}$ & Remarks & \\
\hline$n-\mathrm{SrTiO}_{3} / \mathrm{Pt}$ & $1 \mathrm{M} \mathrm{NaOH}$ & $<1 \%$ & $\begin{array}{l}\text { requires no applied bias; stable; } \\
\text { uv light used }\end{array}$ & Wrighton (1979) \\
\hline$n-\mathrm{Fe}_{2} \mathrm{O}_{3} / p-\mathrm{Fe}_{2} \mathrm{O}_{3}$ & $1 \mathrm{M} \mathrm{NaOH}$ & $0.05 \%$ & $\begin{array}{l}\text { requires no applied bias; visible } \\
\text { light used }\end{array}$ & $\begin{array}{l}\text { Leygraf et al } \\
(1982)\end{array}$ \\
\hline$n-\mathrm{TiO}_{2} / p-\mathrm{LuRhO}_{3}$ & $\mathrm{~K}_{2} \mathrm{SO}_{4}(\mathrm{pH}=7)$ & $0 \cdot 12 \%$ & $\begin{array}{l}\text { requires no applied bias; visible } \\
\text { and uv lights used }\end{array}$ & $\begin{array}{l}\text { Jarrett et al } \\
(1980)\end{array}$ \\
\hline$p$-InP/graphite & $1 \mathrm{M} \mathrm{HClO}_{4}$ & $13 \cdot 3 \%$ & $\begin{array}{l}\text { applied bias; surface modified } \\
\text { with hydrogen-saturated } \mathrm{Rh} \\
\text { islands }\end{array}$ & Heller (1984) \\
\hline
\end{tabular}

*Conversion efficiency, $\eta=\frac{\text { (energy stored as fuel) }- \text { (electrical energy input) }}{\text { (incident solar energy) }}$ 


\section{Recent studies}

Considerable effort has been put in worldwide research in PEC cells during the last two years (Abstracts 1986). The most significant achievement has been the improvement in $\eta$ of LJSC. Thus, $\eta$ values of $20 \%$ with $n-W_{S e}$ and of $15.5 \%$ with $n-G a A s$ semiconductor electrodes have been reported (Azaiez et al 1986; Gabouze and Gorochov 1986). Both these SC's have been investigated by many workers but the improvement in $\eta$ has been effected only through a better crystal growth technique (n-WSe ${ }_{2}$, using $\mathrm{SeCl}_{4}$ as the transporting agent in the CVT technique) (Azaiez et al 1986), or by the use of a new non-aqueous redox electrolyte (for n-GaAs) (Gibbons et al 1984; Gabouze and Gorochov 1986) (see table 1).

Other recent studies carried out on PEC cells can be classified as: (i) new materials-new semiconductors and new growth methods of known materials; (ii) surface modification/protection of known SC materials for PEC studies; (iii) rechargeable batteries and photogalvanic cells; (iv) new experimental techniques for the study of PEC behaviour of semiconductors; (v) theory, models and mechanisms and (vi) devices.

3.1a New materials: A wide variety of pure and mixed oxides, chalcogenides and pnictides have been examined for their PEC behaviour (table 3). Only some of them were found to be photoactive with good stability. It is expected that more materials will be tested for possible breakthroughs.

Table 3. New and novel SC electrodes studied in recent years.

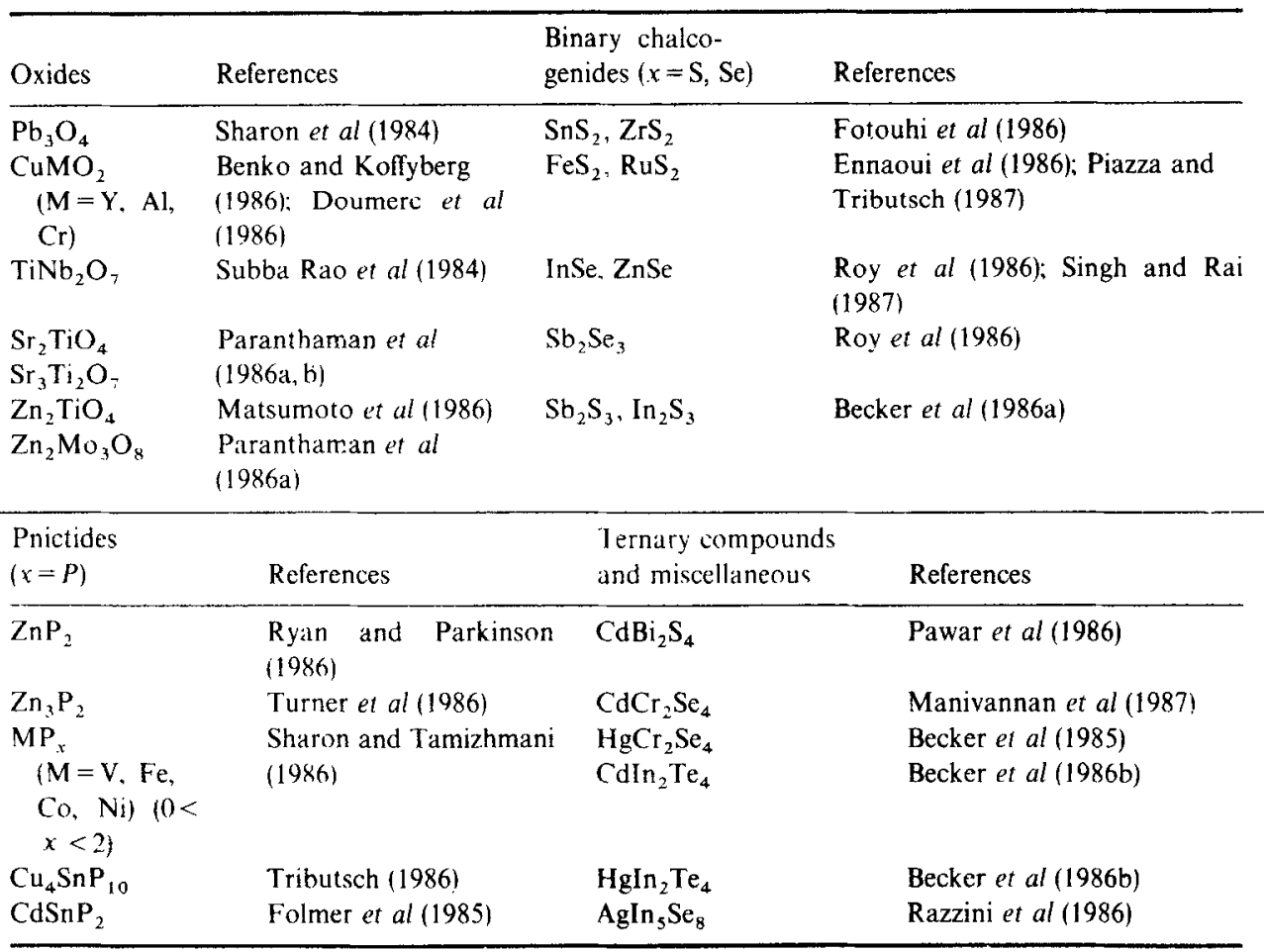


$3.1 \mathrm{~b}$ New growth methods: Selenium tetrachloride $\left(\mathrm{SeCl}_{4}\right)$ was found to be the best transporting agent as compared to $\mathrm{Br}_{2}$ or $\mathrm{I}_{2}$ for the growth of $\mathrm{WSe}_{2}$ single crystals and to achieve high efficiencies (Azaiez et al 1986). Selective doping enhanced the grain size of the crystallites in CuInSe ${ }_{2}$, another well-known PEC material (Ram Janam 1986). Tellurium-substituted cadmium selenide, $\mathrm{CdSe}_{0.65} \mathrm{Te}_{0.35}$ was earlier found to give $\eta \sim 7-8 \%$ in polysulphide electrolyte (Hodes 1980). Levy-Clement et al (1985) found that an $\eta$ value of $12 \%$ can be achieved by modifying the crystal growth technique (vertical Bridgmann under controlled Se pressure).

\subsection{Surface modification/protection of known materials}

GaAs and $\mathrm{CuInSe}{ }_{2}$ electrodes can be suitably modified by coating with thin oxide layers to give enhanced stability and better PEC performance (Kohl et al 1977). GaAs was stabilized in a new electrolyte (Gabouze and Gorochov 1986) (see table 1). Cesium polysulphide electrolyte (as compared to $\mathrm{Na}_{2} \mathrm{~S}$ or $\mathrm{K}_{2} \mathrm{~S}$ ) gives long term stability to the $\mathrm{CeSe}_{0.65} \mathrm{Te}_{0.35}$ (Levy-Clement et al 1985). Photoetching also seems to increase the PEC performances of various materials. CdTe surface was modified with $\mathrm{Ru}$ and $\mathrm{Pt}$ to give better PEC performances (Mandel et al 1986; Bose and Holz 1987).

\subsection{Rechargeable batteries and photogalvanic cells}

Photogalvanic cells use metal electrodes and produce electricity as a result of irradiation of light-absorbing molecules in solution. Albery (1982) set a practical upper limit of about $4 \%$ solar energy conversion efficiency for photogalvanic cells. The best photogalvanic cell so far constructed has an efficiency of only $0.03 \%$ (viz Pt (or $\mathrm{SnO}_{2}$ ) $/ \mathrm{Fe}^{2+/ 3+}$, thionine, leucothionine/Pt).

If the semiconductor electrode and the counter electrode are separated by a suitable membrane and two different redox electrolytes are used in each half cell, it would be possible to oxidize one set of redox electrolytes in one half cell and reduce the other set of redox electrolytes in the other half cell. Here solar energy is used to perform these reactions to charge the cell. The possible use of transition metal phosphide and other semiconductors for the solar chargeable battery has been discussed by Sharon and Tamizhmani (1986).

\subsection{New experimental techniques}

Various new experimental techniques have been developed/applied to study the PEC behaviour. Some of them are: (i) time domain spectroscopy (TDS) for capacitance measurements (Braun et al 1986), (ii) double beam illumination ( $h v \geqslant E_{g} ; h v \lesssim E_{g}$ ) to study intrinsic semiconductors (von Kanel et al 1984), (iii) electromodulated infrared spectroscopy for in situ measurements (Venkateswara Rao et al 1986), (iv) laser spot scanning for correlation of grain boundaries and defects at the SC surface (Carlsson and Holmstrom 1986). (v) photothermal beam depletion technique for in situ observation and detection of unstable species during cell reaction (DortheMerle et al 1986), (vi) electrochemical photocapacitance spectroscopy (EPS) for identification of energy levels and concentrations before and after surface modifica- 
tion of the semiconductors (Mandel et al 1986), and (vii) Raman spectroscopy to identify composition of modified surface (Bose and Holz 1987).

\subsection{Theory, models and mechanisms}

A Schottky barrier theoretical model was developed by Chandra et al (1986) to explain the I-V characteristics and the Fermi-level pinning observed in GaAs PEC cells. Mechanistic studies of etchpit formation by PEC etching were reported by Marcu and Tenne (1986), whereas a kinetic model for the quantized electron transfer from superlattice photoelectrodes ( $\mathrm{GaAs} / \mathrm{GaAs}_{0.5} \mathrm{P}_{0.5}$ ) was proposed by Nozik et al (1986).

\subsection{Devices}

An engineering design for the PEC cell was suggested by Gerischer (1980) (figure 1). This is a modified version of an earlier type.

\section{Emerging trends for PAE and PES cells}

Stable oxides (e.g. $\mathrm{TiO}_{2}$ and $\left.\mathrm{SrTiO}_{3}\right)$ possess large bandgaps $\left(E_{g} \geqslant 3.0 \mathrm{eV}\right)$ and hence cannot utilize sufficient portion of the solar energy for PEC conversion. In order to reduce $E_{g}$ and induce visible-lighr response, doping with transition metal oxides and thin-film metal coatings have been tried without much success (Kalyanasundaram 1985: Rajeshwar 1985; Tributsch 1986: Wrighton 1985). The strategy of the so-called $d$-band oxides and chalcogenides seems to offer good promise. In these compounds (e.g. $\mathrm{MoS}_{2}, \mathrm{RuS}_{2}, \mathrm{MO}_{2} \mathrm{Re}_{4} \mathrm{Se}_{8}, \mathrm{LuRhO}_{3}, \mathrm{Zn}_{2} \mathrm{MO}_{3} \mathrm{O}_{8}$ ), both the $\mathrm{VB}$ and CB arise out of the $d$-electrons and the photoresponse is attributed to the electronic $d \rightarrow d$ (band) transitions. According to Tributsch (1986), these $d$-band chalcogenides can act as excellent photocatalytic materials for PAF of water (figure 2).

More detailed studies can throw further light on the PEC behaviour of the $d$-band materials.

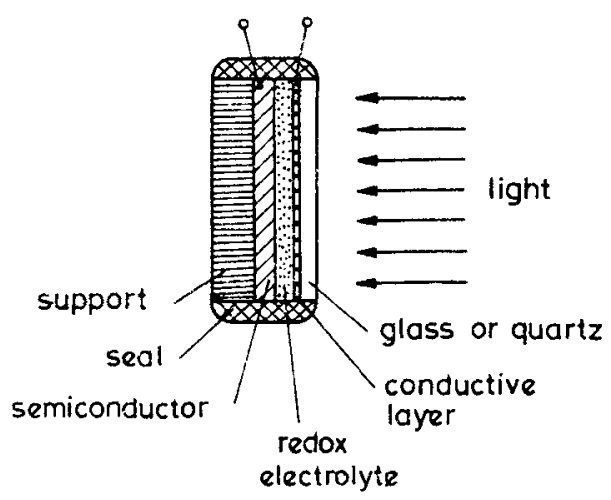

Figure 1. An engineering design of a practical PEC cell for solar energy conversion (Gerischer 1980). 


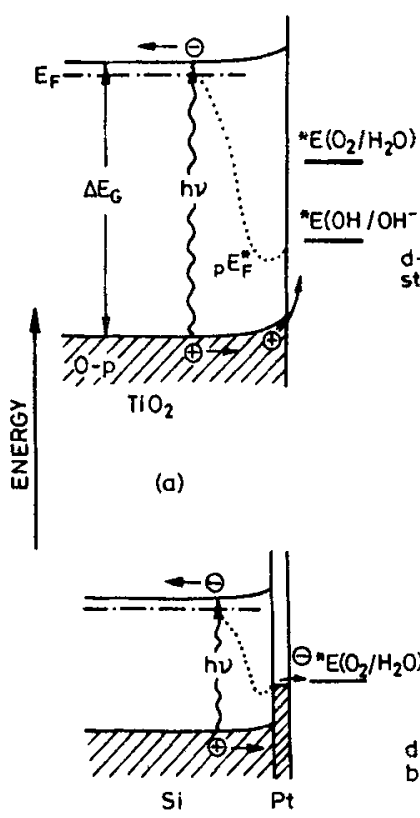

(c)

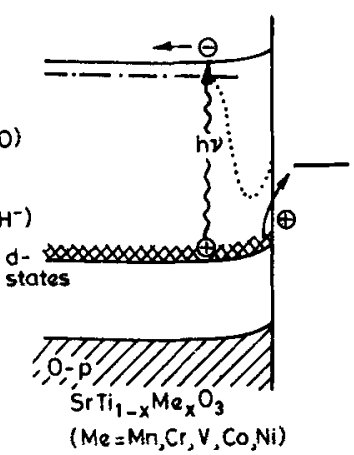

(b)

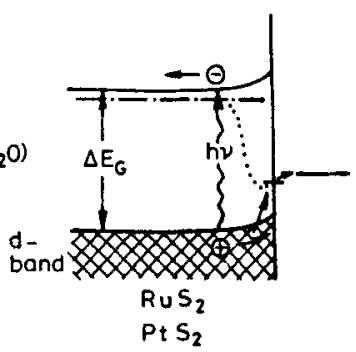

(d)

Figure 2. Different strategies for the development of photoelectrodes for the evolution of oxygen from water: (a) large-band gap oxides; (b) transition metal doped oxides; (c) metal coated low-band gap SC's; (d) d-band sulfides (after Tributsch 1986).

\section{Acknowledgements}

Thanks are due to Dr M Paranthaman for help in the preparation of the manuscript. Thanks are due to DNES, New Delhi for the award of a research grant.

\section{References}

Abstracts 1986 Proc. Sixth Int. Conf. on Photochem. Conv. and Storage of Solar Energy, Paris Albery W J 1982 Acc. Chem. Res. 15142 (and references therein)

Azaiez C, Levy F, Campet G and Claverie J 1986 Paper D-53 of Abstracts 1986

Becker R S, Zhou G D and Elton J 1985 Solar Energy Mater. 12371

Becker R S, Zheng T, Elton J and Saeki M 1986a Solar Energy Mater. 1397

Becker R S, Zhou G D and Elton J 1986b J. Phys. Chem. 905866

Benko F A and Koffyberg F P 1986 Mater. Res. Bull. 21753

Bose D N and Holtz M 1987 Mater. Lett. (in press)

Braun C M, Fujishima A and Konda H 1986 paper D-21 of Abstracts 1986

Cahen D and Chen Y W 1984 Appl. Phys. Lett. 45746

Carlsson P and Holmstrom B 1986 Paper D-7 of Abstracts 1986

Chandra S, Singh S L and Khare N 1986 J. Appl. Phys. 591570

Dorthe-Merle A M, Morand J P and Maurin E 1986 Paper H-15 of Abstracts 1986

Doumerc J P, Ammar A, Wichainchai A and Pouchard M 1986 Paper D-57 of Abstracts 1986

Ennaoui A, Fiechter S, Jaegermann W and Tributsch H 1986 J. Electrochem. Soc. 13397

Folmer J C W, Tuttle J R, Turner J A and Parkinson B A 1985 J. Electrochem. Soc. 1321608

Fotouhi B, Katty A and Gorochov O 1986 Compt. Rend. Paris, Ser. II, Mec. Phys. 3031001

Frese Jr. K W 1982 Appl. Phys. Lett. 40275 
Gabouze N and Gorochov O 1986 Paper D-91 of Abstracts 1986

Gerischer H 1980 Pure Appl. Chem. $\mathbf{5 2} 2649$

Gibbons J F, Cogan G W, Gronet C M and Lewis N S 1984 Appl. Phys. Lett. 451095

Heller A, Miller B and Thiel F A 1981 Appl. Phys. Lett. 38282

Heller A 1984 Science 2231141

Hodes G 1980 Nature (London) 28529

Jarrett H S. Sleight A W, Kung H H and Gillson J L 1980 J. Appl. Phys. 513916

Kalyanasundaram K 1985 Solar Cells 1593

Kohl P A. Frank S N and Bard A J 1977 J. Electrochem. Soc. 124225

Levy-Clement C. Triboulet R, Rioux J, Etcheberry A, Licht S and Tenne R 1985 J. Appl. Phys. 584703

Leygraf C, Hendewerk M and Somorjai G A 1982 Proc. Natl. Acad. Sci. 795739

Mandel K C, Basu S and Bose D N 1986 Solar Cells 1825

Manivannan A, Aruchamy A, Aravamudan G and Subba Rao G V 1987 Solar Energy Mater. 15299

Marcu V and Tenne R 1986 Paper D-1 of Abstracts 1986

Matsumoto Y, Omae M, Watanabe I and Sato E 1986 J. Electrochem. Soc. 133711

Memming R 1980 Electrochim. Acta 2577

Menezes S 1984 Appl. Phys. Lett. 45148

Nozik A J, Thacker B R, Turner J A and Olson J M 1986 Paper D-111 of Abstracts 1986

Paranthaman M, Aravamudan G and Subba Rao G V 1986a Indian J. Technol. 24399

Paranthaman M, Aruchamy A, Aravamudan G and Subba Rao G V 1986b Mater. Chem. Phys. 14349

Pawar S H. Tamhankar S P and Lokhande C D 1986 Solar Energy Mater. 1471

Piazza S and Tributsch H 1987 J. Appl. Electrochem. 17613

Rajeshwar K $1985 \mathrm{~J}$. Appl. Electrochem. 151

Ram Janam 1986 Investigations on synthesis, growth and characterization of chalcopyrite semiconductor CuInSe, in relation to solar cell fabrication. Ph.D. thesis, Banaras Hindu University, Varanasi

Razzini G, Bicelli L P, Arfelli M and Scrosati B 1986 Electrochim. Acta 311293

Roy C B, Nandi P K and Mahapatra P K 1986 Electrochim. Acta 311227

Ryan M A and Parkinson B A 1986 Appl. Phys. Lett. 481754

Sharon M, Sudhir K and Sathe N P 1984 Solar Cells 12353

Sharon M and Tamizhmani 1986 J. Mater. Sci. 212193 (and references therein)

Singh K and Rai J P 1987 Phys. Status Solidi. A99 529

Subba Rao G V, Aruchamy A, Aravamudan G and Paranthaman M 1984 Advances in Hydrogen Energy,

4, Hydrogen energy proyress V 3 (New York: Pergamon Press) Vol. 3, p. 1075

Tributsch H 1986 in Modern aspects of electrochemistry 7 (eds.) J O'M Bockris, B E Conway and R E White (New York: Plenum) No. 17, p. 303

Turner J, Parkinson B A and Bhusan M 1986 J. Electrochem. Soc. 133536

Venkateswara Rao A, Chazalviel J N and Ozanam F 1986 Paper D-33 of Abstracts 1986

von Kanel H, Kaldis E, Wachter P and Gerischer H 1984 J. Electrochem. Soc. 13177

Weber M F and Dignam M J 1986 Int. J. Hyd. Energy 11225

Wrighton M S 1979 Acc. Chem. Res. 12303

Wrighton M S 1985 Pure Appl. Chem. 5757 